\title{
Е.В. Вшивкова
}

Пермский национальный исследовательский политехнический университет

\section{НАПРАВЛЕНИЯ ОПТИМИЗАЦИИ БЮДЖЕТНЫХ РАСХОДОВ НА ФИНАН- СИРОВАНИЕ МУНИЦИПАЛЬНЫХ УЧРЕЖДЕНИЙ КУЛЬТУРЫ (НА ПРИМЕРЕ ГОРОДА ПЕРМИ)}

\begin{abstract}
Анализируются вопросы оптимизации расходов бюджета на финансирование муниципальных учреждений культуры. Рассмотрены такие направления оптимизации: объединение (оптимизация) муниципальных учреждений культуры и введение единой бухгалтерии. На основе традиционного анализа документов сделаны выводы о необходимости решения ключевых проблем организации и финансирования муниципальных учреждений культуры города Перми и разработаны соответствующие рекомендации.

Ключевые слова: местное самоуправление, муниципальные учреждения культуры, оптимизация, объединение, централизация, единая бухгалтерия.
\end{abstract}

Реализация культурной политики - одна из наиболее значимых сфер деятельности органов государственной власти и органов местного самоуправления. От того, как хорошо решаются эти вопросы, зависит степень удовлетворенности культурных потребностей, а также уровень и качество жизни членов общества.

В настоящее время возрастает роль местного самоуправления в решении проблем организации досуга. Так как именно этот уровень управления наиболее близок населению и имеет наиболее полное представление о культурных потребностях и запросах граждан, то включенность органов местного самоуправления в реализацию культурной политики объективна.

Одной из целей регулирования культурной сферы является создание оптимальных условий для всестороннего развития, саморазвития, раскрытия талантов, дарований людей. Этому способствует сеть учреждений культуры и досуга. Основной целью учреждений культуры является передача культурного наследия, обучение навыкам и необходимым знаниям в различных областях, а также приумножение и сохранение культурного наследия. 
Реализация уставных целей учреждений культуры осуществляется в соответствии с муниципальными заданиями. В редакции БК РФ от 26.04.2007 г. дано определение государственного (муниципального) задания (далее плановое задание) как документа, устанавливающего требования к объему, составу, качеству, условиям, порядку и результатам оказания государственных (муниципальных) услуг [1, ст. 69.2.]. Переход от сметного финансирования к финансированию на основе государственного (муниципального) задания позволяет развить и повысить материальную заинтересованность. С 2011 года, согласно Ф3 «О внесении изменений в отдельные законодательные акты РФ в связи с совершенствованием правового положения государственных (муниципальных) учреждений» от 08.05.2010 №83-Ф3, муниципальные учреждения культуры могут оказывать платные услуги, тем самым привлекая в свой бюджет дополнительные средства.

На деле же органы местного самоуправления зачастую сталкиваются с рядом проблем, снижающих эффективность деятельности муниципальных учреждений культуры.

Следует отметить, что, в Пермском крае число организаций культурнодосугового типа ежегодно сокращается. К 2019 году по сравнению с 2013 годом сокращение количества учреждений составило 5,7\% [2]. Отсюда возникает необходимость более детального изучения этого вопроса.

Сегодня всё чаще говорят об оптимизации муниципальных учреждений культуры, подразумевая грамотное концентрированное распределение средств и кадров для создания условий культурно-досуговой и творческой деятельности населения. Оптимизация - это переход на более рациональное управление на всех уровнях, наиболее эффективное использование бюджетных средств. Данная процедура имеет ряд негативных последствий.

Глава города Перми Д.И. Самойлов в докладе «О достигнутых значениях показателей для оценки эффективности деятельности органов местного самоуправления городских округов и муниципальных районов за отчётный 2018 год и их планируемых значениях на 3-летний период» [3] упоминает, 
что в 2019-2021 гг. число муниципальных учреждений культуры сократится с 42 до 41 за счёт реорганизации МАУК ЦДТ «Радуга» путём присоединения к МАУК ПДГК имени С.М. Кирова.

В соответствии с постановлением Администрации города Перми «О Порядке создания, реорганизации, изменения типа и ликвидации муниципальных учреждений города Перми, утверждения уставов муниципальных учреждений города Перми и внесения в них изменений» [4], реорганизация муниципального учреждения (учреждений) может быть осуществлена в форме его слияния, присоединения, разделения или выделения. Решение о реорганизации муниципального учреждения (учреждений) принимается администрацией города Перми в порядке, аналогичном порядку создания муниципального учреждения путем его учреждения, и утверждается постановлением администрации города Перми.

Ярким примером оптимизации служит образование муниципального бюджетного учреждения культуры города Перми «Объединение муниципальных библиотек» (МБУК «ОМБ»). Оно создано 1 января 2000 года, а приобрело статус бюджетного 30 декабря 2011 года. В Объединение входят 37 библиотек, из них 12 - специализированные: 11 - детских библиотек и 1 библиотека для молодежи. Учредителем является Департамент культуры и молодежной политики администрации города Перми.

Тенденция жёсткой оптимизации лучше прослеживается на региональном уровне. Статья «Слияния и поглощения» газеты «Новый компаньон» свидетельствует о том, что «в настоящее время в муниципалитетах Пермского края существует 559 учреждений культуры. К финальному этапу оптимизации в 2021 году их должно остаться 276, то есть количество юридических лиц сократится более чем вдвое $(50,6 \%)$. В наибольшей степени - почти втрое - сократится количество библиотек: 55 вместо 145 (-90). Количество КДУ тоже сократится более чем вдвое: вместо 342 к 2021 году останется лишь 158 (-184). Без изменения останется количество муниципальных театров, детских музыкальных школ и школ искусств» [5]. 
Несмотря на то, что «оптимизация» предполагает действия, при которых достигается наилучшее состояние системы в целом, комплекс проведенных мероприятий в основном ограничен только мерами по сокращению объектов, их реорганизации или сокращению численности работников. Поэтому оптимизация приводит к снижению доступности услуг (в том числе для лиц с OB3), росту безработицы. Также из-за отсутствия информированности населения о причинах осуществления реорганизации учреждений это воспринимается им как губительная процедура для культурного развития общества. В связи с этим следует с большим вниманием отнестись к процедуре оптимизации, грамотно донести до граждан информацию о необходимости её проведения, предотвратив тем самым нарастание социальной напряжённости.

Далее стоит отметить проблему единой бухгалтерии. Централизованные бухгалтерии были созданы как специализированные структурные подразделения при органах государственной власти и органах местного самоуправления, главных распорядителях и распорядителях бюджетных средств. Согласно статье 162 Бюджетного кодекса, одним из полномочий получателя бюджетных средств является ведение бюджетного учета либо передача на основании соглашения этого полномочия иному государственному (муниципальному) учреждению (централизованной бухгалтерии) [1, ст. 162]. В Перми эти полномочия возлагаются на Муниципальное казенное учреждение «Центр бухгалтерского учета и отчетности» города Перми.

МКУ «Центр бухгалтерского учета и отчетности» создано с целью исполнения полномочий органов местного самоуправления по осуществлению функций централизованного ведения бухгалтерского (бюджетного) учета, составления бухгалтерской (бюджетной) отчетности департамента финансов администрации города Перми, администрации города Перми и территориальных органов администрации города Перми, а также подведомственных им муниципальных учреждений администрации города Перми в соответствии с действующим законодательством на основании договоров (соглашений) на 
обслуживание бухгалтерской деятельности, заключенных между МКУ «ЦБУ» и обслуживаемыми учреждениями.

Стоит отметить, что в Пермском крае данную инициативу внёс бывший губернатор М. Решетников. Она заключается в следующем: у каждого учреждения культуры есть своя бухгалтерия, после данной реформы ее приходится упразднить и передать её функции централизованной структуре. Но стоит отметить, что новая структура значительно осложнит работу учреждений культуры, так как для функционирования учреждений культуры требуется реквизит и другие материалы, которые постоянно должны закупаться. Раньше это осуществлялось через свою бухгалтерию. Это требовало минимального количества времени. Введение единой бухгалтерии приведёт к значительной временной задержке. Скорее всего каждого согласования нужно будет ждать не один день. К тому же при создании единой бухгалтерии неизбежно возникнут проблемы с поставщиками материалов, закупаемых учреждениями культуры, что впоследствии грозит отказом от сотрудничества.

По информации сайта «БезФормата», «по словам главного бухгалтера министерства финансов Ирины Антиповой основные проблемы, с которыми столкнулось ведомство при централизации учета финансово-хозяйственной деятельности: низкая степень автоматизации, отсутствие единой методологии в кадровом учете начисления заработной платы, отсутствие оперативности в принятии управленческих решений. По ее словам, в 78\% бюджетных учреждениях не были автоматизированы процессы по кадровому учёту и финансовой отчетности» [6].

Введение единой бухгалтерии ведёт к сокращению штата работников учреждения, а это потеря рабочих мест, которое ведёт к социальной напряжённости. При централизованной бухгалтерии принятие решений затрудняется из-за удаленности обслуживаемых муниципальных учреждений, особенно при обработке большого количества информации. Централизованная бухгалтерия - это также и большие риски, т.к. в случае сбоя в работе может быть нарушена работа всех обслуживаемых учреждений. Также стоит отме164 
тить, что принимаемые решения обязательны для всех дочерних структур, даже если они не соотносятся с интересами конкретного филиала.

На основе рассмотренных проблем определим рекомендации по их решению.

Проблема объединения (оптимизации) муниципальных учреждений культуры требует:

- Во-первых, работы над обеспечением доступности услуг учреждений культуры муниципального образования для всех слоев населения, в том числе выделение дополнительных средств для оснащения всех учреждений культуры муниципального образования необходимыми устройствами, приборами, сооружениями и т.д. для людей с ОВ3.

- Во-вторых, предоставление сокращённым работникам альтернативной работы с хорошей заработной платой и условиями труда.

- В-третьих, разъяснение населению причин оптимизации муниципальных учреждений культуры и дальнейших перспектив развития объединённых учреждений для предотвращения нарастания социальной напряжённости.

Проблема единой бухгалтерии нуждается:

- Во-первых, в проведении высококачественной и эффективной автоматизации бухгалтерии.

- Во-вторых, в предоставлении сокращённым работникам альтернативной работы с хорошей заработной платой и условиями труда.

Итак, выявленные пути развития направления оптимизации бюджетных расходов на финансирования муниципальных учреждений культуры должны включать в себя всесторонние меры по развитию самого учреждения, меры инновационного развития деятельности, ее оценки, отчетности по ней и т.д.

\section{Список литературы}


1. Бюджетный кодекс Российской Федерации от 31.07.1998 N 145Ф3 (ред. от 01.04.2020) // Российская газета. - 1998. - N 153-154.

2. Статистическая девятка. №7 «Культура в Пермском крае»: Территориальный орган Федеральной службы государственной статистики по Пермскому краю [Электронный ресурс].

URL: https://permstat.gks.ru/storage/mediabank/\%D0\%A1\%D1\%82\%D0\%B0\%D 1\%82\%D0\%B8\%D1\%81\%D1\%82\%D0\%B8\%D1\%87\%D0\%B5\%D1\%81\%D0\% BA\%D0\%B0\%D1\%8F\%20\%D0\%B4\%D0\%B5\%D0\%B2\%D1\%8F\%D1\%82\%D0 \%BA\%D0\%B0\%20\%E2\%84\%967 2019.pdf (дата обращения: 01.03. 2020)

3. Пояснительная записка к докладу Главы г. Перми Самойлова Д.И. «О достигнутых значениях показателей для оценки эффективности деятельности органов местного самоуправления городских округов и муниципальных районов за отчётный 2018 год и их планируемых значениях на 3летний период» [Электронный pecypc].

URL:https://www.gorodperm.ru/upload/pages/6575/Pojasnitelnaja_zapiska_k_dok ladu.pdf (дата обращения: 05.04.2020)

4. О Порядке создания, реорганизации, изменения типа и ликвидации муниципальных учреждений города Перми, утверждения уставов муниципальных учреждений города Перми и внесения в них изменений. Постановление Администрации города Перми (с изменениями на 4 апреля 2019 года) [Электронный ресурс]. - URL: http://base.garant.ru/49351384/ (дата обращения: 10.04.2020).

5. Новый компаньон[Электронный ресурс]. - URL: https://www.newsko.ru/(дата обращения: 10.04.2020)

6. Официальный сайт российских региональных новостей «БезФормата» [Электронный ресурс]. - URL: https://perm.bezformata.com/ (дата обращения: 18.04.2020)

\section{E. V. Vshivkova}


Perm National Research Polytechnic University

\section{DIRECTIONS FOR OPTIMIZING BUDGET EXPENDITURES FOR FINANCING MUNICIPAL INSTITUTIONS OF CULTURE (ON THE EXAMPLE OF THE CITY OF PERM)}

The issues of optimization of budget expenditures for financing municipal cultural institutions are analyzed. The following directions of optimization are considered: unification (optimization) of municipal cultural institutions and the introduction of unified accounting. Based on the traditional analysis of documents, conclusions were drawn about the need to solve key problems of organizing and financing municipal cultural institutions of the city of Perm, and appropriate recommendations were developed.

Keywords: local government, municipal cultural institutions, optimization, unification, centralization, unified accounting. 